\title{
Neuromuscular block induced by Bothrops moojeni snake venom and the effect of Jatropha elliptica starch
}

This research evaluated the effect of Bothrops moojeni venom on neuromuscular activity and verified the antiophidian potential of the $J$. elliptica starch (JeP) in this model. The venom was obtained from snakes collected in the state of Tocantins, the protein profile evaluated in electrophoresis (SDS-PAGE), and the activity on the phrenic-diaphragm nerve of mice determined in $50 \mu \mathrm{g} / \mathrm{mL}$ of venom. The JeP, obtained by hand, was sieved in a sieve for granulometric analysis, and concentrations of 100 and $1000 \mu \mathrm{g} / \mathrm{mL}$ were tested to verify its antiophidian potential on the action of the poison. The following models were used: pre-venom addition of venom and after $15 \mathrm{~min}$ addition of JeP; post-poison - addition of JeP and after $15 \mathrm{~min}$ the addition of poison; and pre-incubation - for 30 min, of poison with JeP or commercial antivenom. The poison had proteins from 10 to $60 \mathrm{kDa}$, which induced $50 \%$ of neuromuscular activity block in $71.5 \pm 8.9$ min (T50). The pre-venom and post-venom models with JeP $100 \mu \mathrm{g} / \mathrm{mL}$ prolonged phrenic nerve activity time $(100.9 \pm 7.6 \mathrm{~min}$ and $97 \pm 6.1 \mathrm{~min}$, respectively). The results obtained for $1000 \mu \mathrm{g} / \mathrm{mL}$ and in the model of pre-incubation of the venom with JeP 100 (78.2 \pm 9.2$) ; 1000 \mu \mathrm{g} / \mathrm{mL}$ (86.5 \pm 8.9$)$ and with commercia bothropic antivenom $(80.2 \pm 14.1)$, did not interfere with the activity of the venom on the phrenic nerve. Bothrops moojeni venom induces neuromuscular block and the lower concentration of the starch caused a protective effect on the junction, before and after the administration of the venom.

Keywords: Bothrops moojeni; Neuromuscular junction; Jatropha elliptica; starch.

\section{Bloqueio neuromuscular induzido pelo veneno da serpente Bothrops moojeni e o efeito do polvilho de Jatropha elliptica}

Esta pesquisa avaliou o efeito do veneno de Bothrops moojeni sobre a atividade neuromuscular e verificou o potencial antiofídico do polvilho de J. elliptica (JeP) nesse modelo. $O$ veneno foi obtido de serpentes coletadas no estado do Tocantins, o perfil proteico avaliado em eletroforese (SDS-PAGE), e a atividade sobre 0 nervo frênico-diafragma de camundongos determinada em $50 \mu \mathrm{g} / \mathrm{mL}$ de veneno. O JeP, obtido de modo artesanal, foi tamisado em peneira para análise granulométrica e concentrações de 100 e $1000 \mu \mathrm{g} / \mathrm{mL}$ foram testadas para verificar seu potencial antiofídico sobre ação do veneno. Foram utilizado os modelos: pré-veneno - adição do veneno e após 15 min adição do JeP; pós-veneno - adição do JeP e após 15 min a adição do veneno; e pré-incubação - por 30 min, de veneno com o JeP ou com antiveneno comercial. O veneno apresentou proteínas de 10 a $60 \mathrm{kDa}$, o qual induziu $50 \%$ de bloqueio da atividade neuromuscular em $71,5 \pm 8,9 \mathrm{~min}$ (T50). Os modelos pré-veneno e pós-veneno com JeP $100 \mu \mathrm{g} / \mathrm{mL}$ prolongaram o tempo de atividade do nervo frênico $(100,9 \pm 7,6 \mathrm{~min}$ e $97 \pm 6,1 \mathrm{~min}$ respectivamente). Os resultados obtidos para $1000 \mu \mathrm{g} / \mathrm{mL}$ e no modelo de pré-incubação do veneno com JeP 100 (78,2 299,2$) ; 1000 \mu \mathrm{g} / \mathrm{mL}(86,5 \pm 8,9)$ e com antiveneno botrópico comercial $(80,2 \pm 14,1)$, não interferiram na atividade do veneno sobre o nervo frênico. 0 veneno de Bothrops moojeni induz bloqueio neuromuscular e a menor concentração do polvilho causou efeito protetor sobre a junção, antes e após a administração do veneno.

Palavras-chave: Bothrops moojeni; Junção neuromuscular; Jatropha elliptica; polvilho.

Topic: Uso de Recursos Naturais

Reviewed anonymously in the process of blind peer.
Received: 03/01/2021

Approved: 28/01/2021
Sára Cósta Ferreira-Rodrigues (1D

Universidade Federal do Tocantins, Brasil

http://lattes.cnpq.br/3500845816683964

http://orcid.org/0000-0003-0315-418X

saraalV@hotmail.com

Edson Hideaki Yoshida (iD

Universidade de Sorocaba, Brasil

http://lattes.cnpq.br/5879372846280845

http://orcid.org/0000-0003-0778-9924

ehideakiy@gmail.com

\section{Yoko Oshima-Franco}

Universidade de Sorocaba, Brasil

http://lattes.cnpq.br/0649597834354919

http://orcid.org/0000-0002-4972-8444

yoko.franco@prof.uniso.br

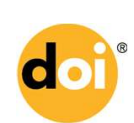

DOI: 10.6008/CBPC2179-6858.2021.001.0052

\author{
Marcio Galdino dos Santos \\ Universidade Federal do Tocantins, Brasil \\ http://lattes.cnpq.br/0838790668957109 \\ http://orcid.org/0000-0002-2570-9425 \\ galdino@mail.uft.edu.br \\ Carla Simone Seibert \\ Universidade Federal do Tocantins, Brasil \\ http://lattes.cnpq.br/6679543572745031 \\ http://orcid.org/0000-0002-3988-7767 \\ seibertcs@uft.edu.br
}

\section{Referencing this:}

FERREIRA-RODRIGUES, S. C.; YOSHIDA, E. H.; OSHIMA-FRANCO, Y.; SANTOS, M. G.; SEIBERT, C. S.. Neuromuscular block induced by Bothrops moojeni snake venom and the effect of Jatropha elliptica starch. Revista Ibero Americana de Ciências Ambientais, v.12, n.1 p.651-662, 2021. DOI: http://doi.org/10.6008/CBPC21796858.2021.001.0052 


\section{INTRODUCTION}

In Brazil, among the snakes of medical interest or the Bothrops (Viperidae) genus, accident incidence rates are considered responsible for $90 \%$ of the changes in the Notification Recordings Information System (SINAN, 2020). The severity of the bothropic accident is marked by intense reactions triggered by various components present in the venom, such as phospholipases, metalloproteases, and serine proteases. The main changes are systemic and are observed in hemostasis and the local ones trigger pain, inflammation, and tissue destruction in the injured limb, which can lead to amputation or death (GUTIÉRREZ et al., 1989; RIBEIRO et al., 1998; BRAUD et al., 2000; PINHO et al., 2001). The treatment for snake venom poisoning has been the administration of antivenom, which improves the immune response, reduces mortality, and neutralizes the clinical symptoms triggered by the poisoning (ALMEIDA et al., 2012).

The state of Tocantins maintains the national epidemiological standard for snakebite accidents, with accidents predominating for rural workers, with the lower limbs being the most affected (FEITOSA et al., 2015; LEOBAS et al., 2016). These accidents are aggravated by the increase in time between the accident and the start of treatment, which is more frequent in rural accidents, due to the distance and difficulty of commuting to the treatment units (GUTIÉRREZ et al., 2011; FEITOSA et al., 2015; LEOBAS et al., 2016; CÂMARA et al., 2020). In the state of Tocantins, patients treated in the first hour after the accident represented $24 \%$ of the notifications (1640 bothropic accidents), a percentage lower than that observed in Brazil (27\% of bothropic accidents).

Thus, the search for alternatives against the effects of snake poisoning becomes a necessity (FONSECA et al., 2004), mainly for populations that live far from hospital units. They often make use of medicinal plants as an alternative to minimize the deficiencies of primary health care, which includes ophidism (CASTRO et al., 2004; SOARES et al., 2005; COSTA et al., 2011).

Due to the relevance of the effects caused by bothropic poisoning, some species of plants are being studied to prove the popular use of antiophidian activity (ASSAFIM et al., 2011; FERRAZ et al., 2014; TRIBUIANI et al., 2014), including Jatropha elliptica (Pohl.) Müll. Arg. This plant is characteristic of the Brazilian cerrado (PAULA et al., 2010; CORDEIRO et al., 2015; FERREIRA-RODRIGUES et al., 2016) whose loss of biodiversity has been aggravated as a result of various activities, such as agricultural activity (CALDEIRA et al., 2020). It is used in the treatment of various diseases, inflammations and indicated for snakebites (VAN DER BERG et al., 1988; LIMA et al., 2006; SILVA et al., 2010; GOMES et al., 2016; YAZBEK et al., 2016).

So far, research on Jatropha elliptica extracts or secondary metabolites ratifies the medicinal potential of this plant and validated its activity on some of the symptoms of ophidian poisoning (BRUM et al., 2006; LIMA et al., 2006; PESSOA et al., 1999; 2007; FERREIRA-RODRIGUES et al., 2016). However, an ethnobotanical study also describes the use of powder (starch), obtained from the rhizomes of the plant, administered orally and in small amounts as a treatment for this type of poisoning (SANTOS et al., 2006), which still needs to be investigated.

In the Tocantins, the most incident snake of medical interest is Bothrops moojeni (SILVA et al., 2017), and there are no studies that evaluate the toxicity of its poison, nor about the neuromuscular 
junction. Therefore, to fill these gaps, the present study aimed to evaluate the effect of Bothrops moojeni venom on neuromuscular activity and to verify the antiophidian potential of J. elliptica (JeP) starch in this model.

\section{MATERIALS AND MÉTHODS}

\section{Obtaining plant rhizomes}

The collection of rhizomes of Jatropha elliptica (Location: S 10 19.207' and W 047 47.954') was carried out in 2019, as described by Ferreira-Rodrigues et al. (2016), in the municipality of Santa Tereza (TO). The plant was identified according to the International Code of Botanical Nomenclature and compared to the exsiccates deposited in the herbarium of the Federal University of Tocantins (UFT), Porto Nacional Campus (Record n. 10.681).

\section{Obtaining the Jatropha elliptica (JeP) starch}

The starch was obtained by a small-scale process. The rhizomes $(1,815 \mathrm{~kg})$ of the plant were washed and grated in a conventional drain, adding water, then sifted and set for decanting. After decanting, the supernatant was removed and the remainder dried at room temperature and later was sifted in a Granutest (Bertel Metalúgica Ltda.) sieve for granulometric analysis, Tyler $80(0.180 \mathrm{~mm})$. The starch yield was 124.7g. The JeP did not solubilize in dimethyl sulfoxide or polyethylene glycol 400 (PEG 400), recommended for use in neuromuscular preparation (CINTRA-FRANCISCHINELLI et al., 2008), which is why dilution in Tyrode and ultrasonication have opted, for 10 minutes, before the addition to the bath.

\section{Obtaining Bothrops moojeni poison}

Samples from the first extraction of crude venom from Bothrops moojeni were obtained from six snakes. The animals were collected in rural areas of the municipalities of Araguaína (two females), Palmas (one male and two females), and Santa Rosa (one female), in the state of Tocantins, in the years 2016 and 2017. The capture of the animals received the scientific authorization № 52416-1 of the Biodiversity Authorization and Information System (SISBIO). The procedure followed Normative Instruction 03/2014 and the biological material was registered in the National System for the Management of Genetic Heritage and Associated Traditional knowledge (SisGen no A2C170C). The venom (Pool / TO) was collected before the first feeding in captivity, lyophilized, and stored at $-20 \circ \mathrm{C}$. The procedures were performed at the Herpetology Laboratory-IB of the Butantan Institute-SP, certified by Dr. Sávio Stefanini.

\section{SDS-PAGE Electrophoresis}

The protein profile of the venom was analyzed by polyacrylamide gel electrophoresis (SDS-PAGE) (LAEMMLI, 1970) using a concentration of $4 \%$ in the application gel and $10 \%$ in the running gel (200v; $40 \mathrm{~mA}$ and $20 \mathrm{~W})$. The venom samples $(10 \mu \mathrm{g})$ were applied in the presence of $\beta$-mercaptoethanol and in parallel, a 10 to 250 kDa molecular mass standard, Dual Color Precision Plus (Bio-Rad) was used. The electrophoresis 
gel was stained with Coomassie-Bio Rad.

\section{Venom neutralization tests}

\section{Commercial Bothropic Antivenom (CBA)}

Bothropic antivenom (CBA) was donated by the Butantan Institute and the experiments were carried out following the doses recommended in the CBA description leaflet (batch: 180187, production date: 03/2018, expiration date: 06/2021), namely: each $\mathrm{mL}$ neutralizes $5 \mathrm{mg}$ of venom of $B$. jararaca reference.

\section{Animals used and experimental conditions}

Male Mus musculus Swiss mice (25-30g) were acquired from Anilab (Laboratory Animals, Paulínia, $\mathrm{SP}, \mathrm{Brazil)}$, kept in chambers with exhausts and appropriate ventilation (environmental micro ventilation system, Smaflex $\left.{ }^{\circledR}\right)$, with controlled temperature $\left(25 \pm 3^{\circ} \mathrm{C}\right)$ in 12-hour light-dark cycles, controlled by a timer, where they received feed and water ad libitum in the bioterium of the University of Sorocaba/SP, following the COBEA Animal Welfare Rules, with a project approved by the Ethics of Animal Use of the same institution (CEUA Report 163/2019).

\section{Phrenic nerve-diaphragm preparation (PND) of mice}

The phrenic nerve-diaphragm preparation of mice was isolated after anesthetizing the animals with halothane (Cristália, Brazil) and killing them by exsanguination. After recording in control conditions for 15 minutes of preparation stabilization, pharmacological protocols and myographic recording were performed according to Farrapo et al. (2011).

A starch concentration-response curve was performed using $100 \mu \mathrm{g} / \mathrm{mL}(\mathrm{n}=6), 200 \mu \mathrm{g} / \mathrm{mL}(\mathrm{n}=5)$ and $1000 \mu \mathrm{g} / \mathrm{mL}(\mathrm{n}=10)$. Tyrode's nutrient solution represented the control condition. The 100 and 1000 $\mu \mathrm{g} / \mathrm{mL}$ concentrations of JeP were subsequently analyzed with $50 \mu \mathrm{g} / \mathrm{mL}$ of $B$. moojeni venom $(\mathrm{n}=9)$, using three models (Table 1).

Table 1: Protocols and the number of experiments.

\begin{tabular}{|c|c|c|}
\hline Models & $\begin{array}{l}\mathrm{JeP} \\
100 \mu \mathrm{g} / \mathrm{mL}\end{array}$ & $\begin{array}{l}\text { JeP } \\
1000 \mu \mathrm{g} / \mathrm{mL}\end{array}$ \\
\hline PreV: JeP* added 15 min before the venom & $\mathrm{n}=9$ & $\mathrm{n}=13$ \\
\hline postV: JeP added 15 min after the venom & $\mathrm{n}=8$ & $n=6$ \\
\hline $\begin{array}{l}\text { Pre-Incubation ( } 30 \text { min, before adding to the organ bath): } \\
\text { Pool/TO + JeP or Pool/TO + CBA* }\end{array}$ & $\mathrm{n}=7$ & $\mathrm{n}=7$ \\
\hline
\end{tabular}

*JeP, starch obtained from rhizomes of Jatropha elliptica

*CBA, Commercial Bothropic Antivenom

\section{Análise Estatística}

\section{Statistical analysis}

The results were expressed as mean \pm standard error of the mean and significance was determined by the unpaired t-Student test. The level of significance was set at $p<0.05$, using the Origin 8.0 software 
(OriginLab Corporation, Northampton, MA, USA).

\section{RESULTS AND DISCUSSION}

The protein profile of the venom from Bothrops moojeni snakes (in SDS PAGE 10\%), is shown in Figure 1. The proteins expressed in greatest intensity, in the gel, were those with a molecular mass around 10,20 , and $45 \mathrm{kDa}$. The importance of studying the composition of the venom is highlighted, since the constituents influence differently the effects of poisoning and, consequently, the necessary treatment (CASEWELL et al., 2014).

The molecular standard values allowed us to infer that the $14 \mathrm{kDa}$ protein belongs to the phospholipase class (CALGAROTTO et al., 2008) and the one with $20 \mathrm{kDa}$ to the metalloproteinases (MESH, 2020). It is also possible to observe the presence of proteins between 20 and $50 \mathrm{kDa}$, almost undetectable in the gel, which shows little expressiveness of them in this material, such as serine proteases ( 32 kDa) (BHAT et al., 2016; OLIVEIRA et al., 2016). Proteins around $50 \mathrm{kDa}$, on the other hand, belong to the hemorrhagic factor class, with intense proteolytic activity (CRISTINA et al., 2020), and have not yet been described for the B. moojeni venom. Pool/TO did not present proteins with molecular weight above $50 \mathrm{kDa}$.

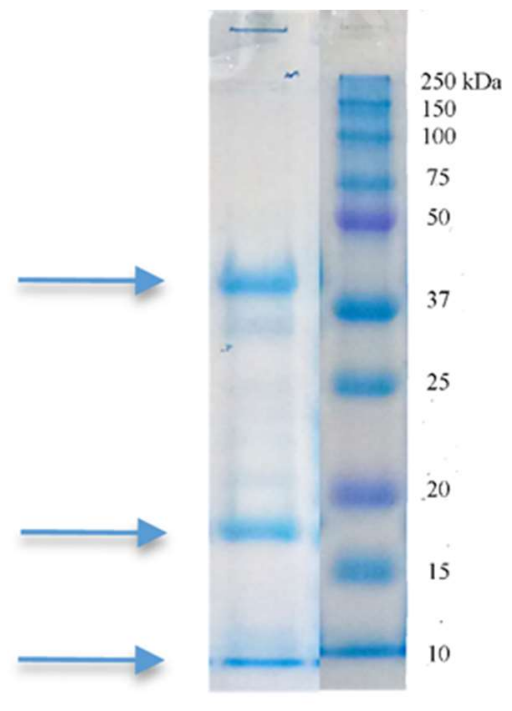

\section{3}

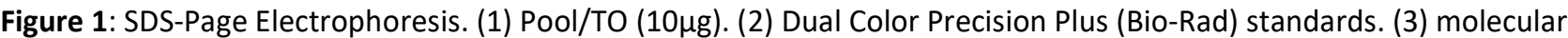
markers $(\mathrm{kDa})$. The arrows indicate differential bands expressed in Pool/TO. The proteins were stained with Coomassie-Bio Rad according to the manufacturer's instructions. Pool/TO, pool of venom collected from 6 Bothrops moojeni snakes.

There are no studies with the $B$. moojeni venom using the experimental model on the neuromuscular junction, that is, the neuromuscular preparation of mammals. The chosen venom concentration of $50 \mu \mathrm{g} / \mathrm{mL}$ was based on studies with other bothropic venoms, performed on the same model (GALBIATTI, 2008; PUEBLA et al., 2010; CARDOSO, 2011; FERRAZ et al., 2014; TRIBUIANI et al., 2014; FERREIRA-RODRIGUES et al., 2016).

Therefore, at this concentration, the B. moojeni venom caused $50 \%$ of neuromuscular block in a time of T50 $=71.5 \pm 8.9 \mathrm{~min}(\mathrm{n}=9$ ). Figure 2 illustrates a myographic recording representing the number of 
experiments carried out with B. moojeni venom exposed to neuromuscular preparation for 120 minutes.

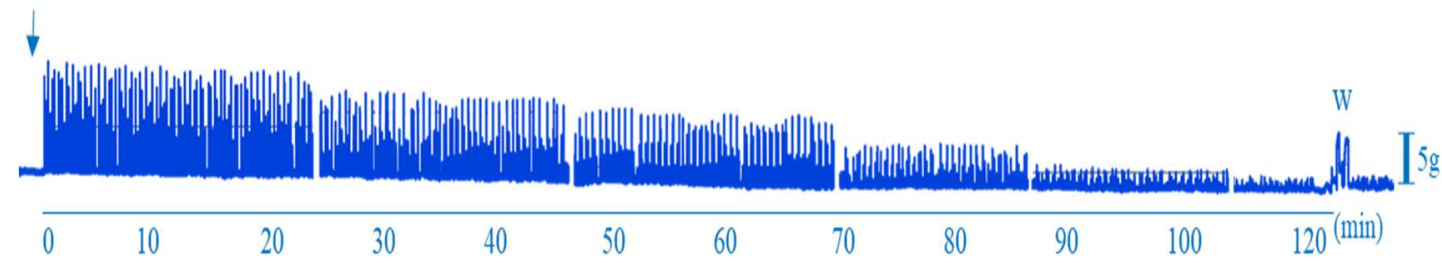

Figure 2: Myographic recording representative of the neuromuscular block induced by Pool/TO ( $50 \mu \mathrm{g} / \mathrm{mL})$. The arrow represents the time of addition of the poison and the T50 of $71.5 \pm 8.9 \mathrm{~min}$. W, washing of the preparation. Pool/TO, a pool of venoms collected from $B$. moojeni snakes from the state of Tocantins

Snake venoms are sometimes more active, sometimes less active, with variation in the blocking time at the neuromuscular junction (OLIVEIRA et al., 2019), a parameter that also depends on the species, such as, for example, the B. jararacussu venom, which at a concentration of $40 \mu \mathrm{g} / \mathrm{mL}$ led to a $50 \%$ block, in a time of $56.2 \pm 8.3 \mathrm{~min}(T 50 ; n=4)$ (FERREIRA-RODRIGUES, 2016). On the other hand, it is known that differences in the proportion and composition of venoms influence their toxicity, as revealed by proteomic studies (CHIPPAUX et al., 1991; BRAUD et al., 2000; CASTRO et al., 2004; BRAHMA et al., 2015; YIN et al., 2016; AMORIM et al., 2017).

It is important to note that Pool/TO expressed a small number of serine proteases (Figure 1), which may explain the greater T50\% block in this pool. Another possibility is related to the intense local myotoxic effect caused by bothropic venom (NISHIJIMA et al., 2015), also observed in neuromuscular preparation (FERREIRA-RODRIGUES et al., 2016). Possivelmente a ação local mascare, reduza ou mesmo limite a ação neurotóxica do veneno botrópico.

The venoms have toxins that cause neuromuscular paralysis in vitro, and this has been explained by the presence of components that can act both presynaptically, blocking the release of acetylcholine (ACh), as well as postsynaptically, blocking its receptors, or even destroying the skeletal muscle architecture, causing myonecrosis (RODRIGUES et al., 2004). Therefore, our study demonstrated that B. moojeni venom also causes an important block in isolated mouse preparations, similar to the venom of other snake species (GALBIATTI, 2008; PUEBLA et al., 2010; CARDOSO, 2011; FERRAZ et al., 2014; TRIBUIANI et al., 2014; FERREIRA-RODRIGUES et al., 2016). However, further studies are needed to elucidate the mechanisms involved. Popularly, some species of plants are used to minimize or neutralize the effects of poisoning by snakes due to the severity of accidents, and also due to the time of access to treatment, especially in rural areas, which are far from healthcare (MOURA et al., 2015).

Included in this context is the Jatropha elliptica plant, with occurrences in the Brazilian cerrado, known as "purga-de-lagarto", "erva-de-teiú", "batata-de-tiú", among others. It is found in the states of Alagoas, Pernambuco, Mato Grosso, Goiás, Bahia and Tocantins and can be observed during the transition from the dry to the rainy season, having a seasonal characteristic (GOULART et al., 1993; SILVA et al., 1998; CORDEIRO et al., 2015).

Concerning medicinal use, the ethnobotanical and pharmacological information reveals that in the regions where it occurs, its root is widely used in popular medicine as a bactericide, depurative, against 
venereal diseases, itches and for ophidian treatment (VAN DEN BERG et al., 1988; LIMA et al., 2006; SANTOS et al., 2006; YAZBEK et al., 2016).

To minimize the effects of snake poisoning, the traditional use of J. elliptica includes the root powder (starch) for the treatment (SANTOS et al., 2006), in the cerrado region of Tocantins, and is done by oral administration, in small amounts. This important information guided the present study and used the experimental model of the neuromuscular junction, by the myographic technique, as a tool for the scientific validation of ethnobotanical extracts of various plants against venoms and toxins (OSHIMAFRANCO and DAL BELO, 2017). For this, hand-made starch was obtained, and since there were no previous studies on the starch response, a concentration-response curve was performed with 100, 200, and 1000 $\mu \mathrm{g} / \mathrm{mL}$ of starch, in this experimental model (Figure 3). Figure 3 illustrates JeP concentrations $100 \mu \mathrm{g} / \mathrm{mL}(\mathrm{n}$ = 6); $200 \mu \mathrm{g} / \mathrm{ml}(\mathrm{n}=5) ;$ and $1000 \mu \mathrm{g} / \mathrm{mL}(\mathrm{n}=10)$, which were added to the vat containing the neuromuscular preparation.

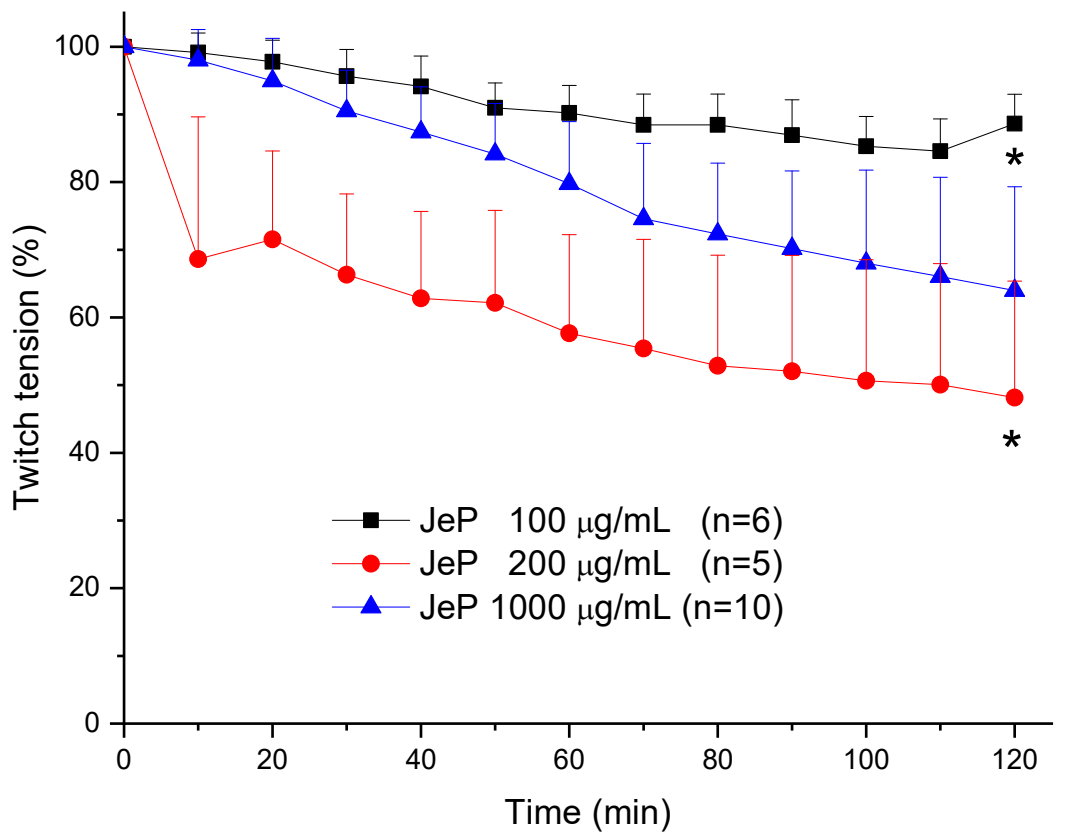

Figure 3: Phrenic nerve-diaphragm preparation of mice, indirect stimulus. Concentration-response curve of the starch (JeP 100, 200 and $1000 \mu \mathrm{g} / \mathrm{mL}$ ). The number of experiments is shown in the labels. Each point represents M \pm EPM. * $\mathrm{p}<0.05$ compared to the concentration that caused the lowest baseline change.

From these results, two concentrations were selected for the subsequent neutralization tests, 100 $\mu \mathrm{g} / \mathrm{mL}$, because it caused the lowest baseline change in the contractile response, and $1000 \mu \mathrm{g} / \mathrm{mL}(\mathrm{p}<0.05$, compared to lowest concentration), as it is 10 times more concentrated. Thus, the amount of JeP to counteract the action of the venom can be tested.

Interestingly, the concentration of $200 \mu \mathrm{g} / \mathrm{mL}$ of JeP reduced neuromuscular activity more sharply than the concentration of $1000 \mu \mathrm{g} / \mathrm{mL}$, which may be related to the technical procedure, as in this set of experiments the powder was not sonicated, which could have influenced the results.

The results obtained with the JeP starch against the neuromuscular block induced by Pool/TO are shown in Figure 4 concerning the time to block $50 \%$ of the contractile response. The pre-venom and postvenom treatments with JeP $100 \mu \mathrm{g} / \mathrm{mL}$ were statistically significant, increasing the activity time to $100.9 \pm$ 
$7.6(n=9)$ and $97 \pm 6.1(n=8)$, respectively. It was also observed that the increase in JeP concentration to $1000 \mu \mathrm{g} / \mathrm{mL}$ (10 times) was insignificant to improve phrenic nerve activity time, not differing significantly from the blocking time triggered by the venom (Pool/TO $\mu \mathrm{g} / \mathrm{mL}$ ) T50 on all experimental models. The JeP pre-incubation model showed an effect similar to that produced by the commercial antivenom ( $p>0.05)$, with both concentrations of the starch, however, without a statistically significant difference when compared to the venom. Differences in the protective ability of antivenoms against certain effects of poisons have been reported in the literature (SEGURA et al., 2016; ESTEVÃO et al., 2016; GUTIÉRREZ, 2017).

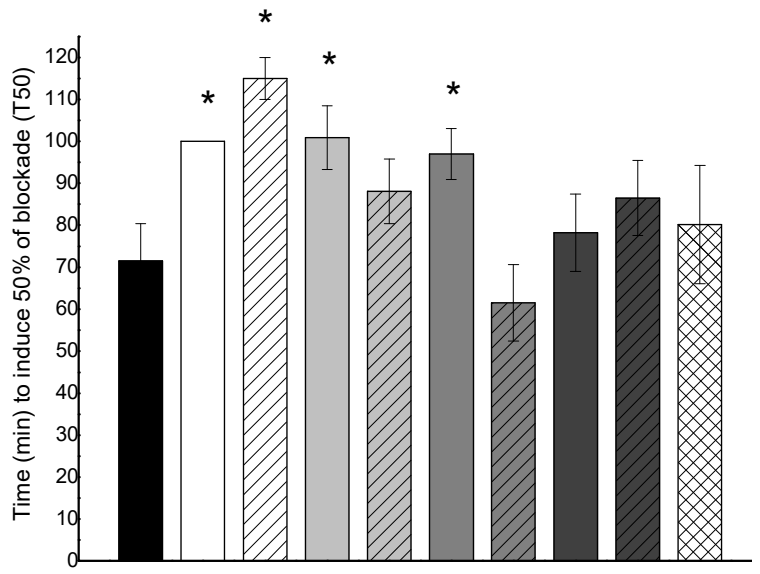

Figure 4: Phrenic nerve-diaphragm preparation of mice, indirect stimulus. Time to block 50\% (T50) of each experimental model against 100 or $1000 \mu \mathrm{g} / \mathrm{mL}$ of JeP, as following: $\square$ B. moojeni $50 \mu \mathrm{g} / \mathrm{mL}$ ( $\mathrm{n}=9$ ); $\square$ JeP 100

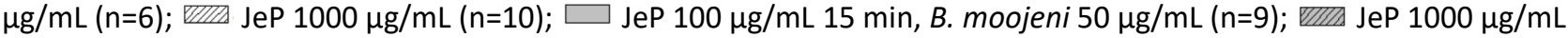
$15 \mathrm{~min}$, B. moojeni $50 \mu \mathrm{g} / \mathrm{mL}(\mathrm{n}=13) ; \square$ B. moojeni $50 \mu \mathrm{g} / \mathrm{mL} 15 \mathrm{~min}$, JeP $100 \mu \mathrm{g} / \mathrm{mL}(\mathrm{n}=8)$; खाय B. moojeni $50 \mu \mathrm{g} / \mathrm{mL}$ $15 \mathrm{~min}$, JeP $1000 \mu \mathrm{g} / \mathrm{mL}(\mathrm{n}=6)$; Pre-incubations B. moojeni $50 \mu \mathrm{g} / \mathrm{mL}+\mathrm{JeP} 100 \mu \mathrm{g} / \mathrm{mL}(\mathrm{n}=7)$; B. moojeni $50 \mu \mathrm{g} / \mathrm{mL}+$ JeP $1000 \mu \mathrm{g} / \mathrm{mL}(\mathrm{n}=7)$; Pre-incubations $B$. moojeni $50 \mu \mathrm{g} / \mathrm{mL}+$ antivenom $(\mathrm{n}=7)$. Note that the statistically significant differences $(* p<0.05)$ were demonstrated. Each column represents $M \pm E P M$. B. moojeni represents Pool/TO, pool of venoms collected from B. moojeni snakes from the state of Tocantins, JeP, starch obtained from rhizomes of J. elliptica.

Several species of plants have been studied from the perspective that, if some anti-ophidian activity is proven, they become possible adjuvants to the commercial antivenom, an effective treatment officially recommended for ophidian poisoning (WHO, 2018; GOMES et al., 2016). As examples, there are studies with the plant Hypericum laxiusculum (Hypericaceae) against the local effects of Bothrops jararaca venom (ASSAFIM et al., 2011) and Jatropha molissima against local effects induced by Bothrops erythromelas and Bothrops jararaca venom (GOMES et al., 2016).

Therefore, the validation of traditional knowledge is increasingly important in the scientific community, using protocols that contribute to the indication of medicine that can be used as an adjunct to conventional serum therapy, not only for the cerrado region, where the studied species occurred. Thus, the present study represents an advance in the determination of the antiophidian property of J. elliptica on the action of the venom of $B$. moojeni, concerning the use of the starch, confirming popular information.

However, other ways of extracting the components of the rhizome of this plant were used to investigate the action of snake venoms. The aqueous extract was effective against the action of the Lachesis muta venom about hemolysis, hemorrhage, coagulation, and proteolytic activity (PAULA et al., 2010). 
The crude ethanolic extract also showed significant anti-inflammatory activity on the classic models of paw edema and neutrophil migration induced by Bothrops jararacussu venom. At the neuromuscular junction, the same extract prevented the evolution of paralysis, and histological analysis confirmed the protective effect by reducing the myotoxic index $(\mathrm{IM})(\mathrm{p}<0.05)$ by up to three times, that is, it reduced the damage caused by the venom, namely, myonecrosis, edema, rupture of the membrane and presence of phantom cells. This protective effect was attributed to phenolic compounds, alkaloids (FERREIRARODRIGUES et al., 2016). Milad et al. (2014) affirm the need to establish a correlation between the presence of secondary metabolites, their effect, and popular usage. This highlights the relevance of further studies on the biological activity of these plants.

Obtaining the starch by hand persuades us to think that, during processing by decantation, portions of the secondary metabolites remain impregnated, causing their protective effect, and/or that the carbohydrate provides energy for the cell to respond more effectively against the actions of the poison. The studies by Bento et al. (2020) confirmed the presence of phenolic compounds in "batata-de-teiú" flour (12.67 mg eq gallic acid $100 \mathrm{~g}^{-1}$ ), with antioxidant potential and nutraceutical resources. These results contribute to our hypothesis; however, new studies need to be carried out to elucidate the protective mechanism of the starch.

According to Moura et al. (2015), the search for a plant antidote against snake poisoning has been long. The rationale for indicating a plant with antivenom potential is complex (VILAR et al., 2005; MOURA et al., 2015), because there is no bioactive compound capable of interacting with the venom antigen as the antibody does. However, any plant that attenuates or blocks the progression of a poisoning event should be valued, for further prospection studies, mainly those from traditional knowledge, due to the known difficulties in accessing serum therapy, or even where its availability is non-existent (SOARES et al., 2005).

\section{CONCLUSIONS}

Our study showed that the venom of B. moojeni, from specimens collected in the cerrado of Tocantins, caused an important neuromuscular block in isolated preparations of phrenic nerve-diaphragm from mice. It also proved experimentally, for the first time, the protective effect of Jatropha elliptica (JeP) starch, when used in a lower dose, immediately before or after the addition of Bothrops moojeni venom.

The results presented here ratify the neuromuscular junction as an important tool for the study of bioactive substances, also taking into account the high incidence of bothropic accidents in the Tocantins, as well as the high diversity of species of antiophidian plants used by populations living in the cerrado, that still lack scientific validation.

ACKNOWLEDGMENTS: The authors thank Fundação de Amparo à Pesquisa do Estado de São Paulo (FAPESP, grants nos. 2004/09705-8; 2007/53883-6; 2008/50669-6; 2008/52643-4; and 2015/01420-9). This work was financed by CAPES, PROCAD 2013 project: Strengthening of Postgraduate Programs, in the Amazon and Extra-Amazon, with emphasis on ophidian poisoning: a strategy for personnel training and 
interdisciplinarity; and doctoral scholarship on social demand (PGCiamb). Research Support Foundation of the State of Tocantins/FAPT (Public Notice PPSUS 01/2018, Agreement 835798/2016).

\section{REFERENCES}

ALMEIDA, J. S. C. B.; SOUZA, D. P. S.; ROCHA, C. L.; SILVA, S. L. C.. Antivenom serum therapy: treatment of adverse reactions. Medical Magazine of Minas Gerais, Belo Horizonte, v.22, n.8, p.S1-S48, 2012.

AMORIM, F, G.; MORANDI FILHO, R.; FUJIMURA, P. T.; UEIRA-VIEIRA, C.; SAMPAIO, S. V.. New findings from the first transcriptome of the Bothrops moojeni snake venom gland. Journal Toxicon, London, v.140, n.15, p.105-117, 2017. DOI: https://doi.org/10.1016/j.toxicon.2017.10.025

ASSAFIM, M.; CORIOLANO, E. C.; BENEDITO, S. E.; FERNANDES, C. P.; LOBO, J. F. R.; SANCHEZ, E. F.; ROCHA, L. M.; FULY, A. L.. Hypericum brasiliense plant extract neutralizes some biological effects of Bothrops jararaca snake venom. Journal of Venom Research, Oxford, v.2, p.116, 2011.

BENTO, J. A. C.; FIDELIS, M. C.; SOUZA NETO, M. A.; LIÃO, L. M.; CALIARI, M.; JÚNIOR, M. S. S.. Physicochemical, structural, and thermal properties of "batata-de-teiú" starch. International Journal of Biological Macromolecules, v.145, p.332-340, 2020. Dol: https://doi.org/10.1016/j.ijbiomac.2019.12.208

BHAT, S. K.; JOSHI, M. B.; ULLAH, A.; MASOOD, R.; BILIGIRI, S. G.; ARNI, R. K.; SATYAMOORTHY, K.. Serine proteinases from Bothrops snake venom activate PI3K/Akt mediated angiogenesis. Toxicon, London, v.124, p.63-72, 2016. DOI: https://doi.org/10.1016/j.toxicon.2016.11.001

BRAHMA, R. K.; MCCLEARY, R. J. R.; KINI, R. M.; DOLEY, R.. Venom gland transcriptomics for identifying, cataloging, and characterizing venom proteins in snakes. Toxicon, London, v.93, p.1-10, 2015. DOI:

https://doi.org/10.1016/j.toxicon.2014.10.022

BRAUD, S.. Snake venom proteins acting on hemostasis. Revista Biochimie, Paris, v.82, n.9-10, p.851-859, 2000.

BRUM, R. L.; CARDOSO, C. A. L.; HONDA, N. K.; ANDREU, M. P.; VIANA, L. S.. Quantitative Determination of Jatrophone in "Cachaça" Prepared with Jatropha elliptica. Chemical and Pharmaceutical Bulletin, Kumamoto, v.54, n.5, p.754-757, 2006. DOI: https://doi.org/10.1248/cpb.54.754

CALGAROTTO, A. K.; DAMICO, D. C. S.; PONCE-SOTO, L. A.; BALDASSO, P. A.; SILVA, S. L.; SOUZA, G. H. M.; EBERLIN, N. M.; MARANGONI, S.. Biological and biochemical characterization of new basic phospholipase A2 BmTX-I isolated from Bothrops moojeni snake venom. Toxicon, London, v.51, n.8, p.1509-1519, 2008. DOI: https://doi.org/10.1073/pnas.1405484111

CÂMARA, O. F.; SILVA, D. D.; HOLANDA, M. N.; BERNARDE, P. S.; SILVA, A. M.; MONTEIRO, W. M.; LIMA, M. V. M.; MONTEIRO, A.; WAJNSZTEJN, R.. Ophidian envenomings in a region of Brazilian Western Amazon. Journal of Human Growth and Development, v.30, n.1, p.120-128, 2020. DOI: https://doi.org/10.7322/jhgd.v30.9958

CARDOSO, F. F.. Action of vegetable compounds on the activity of Piratoxin-I, isolated from Bothrops pirajai venom, in neuromuscular preparation of mice. Dissertation (Master in Biological Sciences) - Universidade Estadual Paulista, Botucatu, 2011.

CALDEIRA, C.; PARRÉ, J. L.. Agricultural diversification and rural development in the cerrado biome. American Journal of Entrepreneurship and Innovation, Curitiba, v.2, n.1, p.344-359, 2020.

CASEWELL, N. R.; WAGSTAFF, S. C.; WÜSTER, W.; COOK, D. A. N.; BOLTON, F. M. S.; KING, S. I.; PLA, D.; SANZ, L.; CALVETE, J. J.; HARRISON, R. A.. Medically important differences in snake venom composition are dictated by distinct postgenomic mechanisms. Proceedings of the National Academy of Sciences of the United States of America, Sacramento, v.111, n.25, p.9205-9210, 2014. DOI: https://doi.org/10.1073/pnas.1405484111

CASTRO, H. C.; ZINGALI, R. B.; ALBUQUERQUE, M. G.; PUJOLLUZ, M.; RODRIGUES, C. R.. Snake venom thrombin-like enzymes: From reptilase to now. Cellular and Molecular Life Sciences, Berlin, v.61, p.843-856, 2004. DOI: https://doi.org/10.1007/s00018-003-3325-z

CHIPPAUX, J. P.; WILLIAMS, V.; WHITE, J.. Review Article: Snake Venom Variability: Methods of Study, I Results and Interpretation. Toxicon, London, v.29, n.2, p.1279-1303, 1991.

CINTRA-FRANCISCHINELLI, M.; SILVA, M. G.; ANDRÉO-FILHO, N.; GERENUTTI, M.; CINTRA, A. C.; GIGLIO, J. R.; LEITE, G. B.; CRUZ-HÖFLING, M. A.; RODRIGUES-SIMIONI, L.; OSHIMAFRANCO, Y.. Antibothropic action of Casearia sylvestris Sw. (Flacourtiaceae) extracts. Phytotherapy Research, v.22, n.6 p.784-790, 2008. DOI: https://doi.org/10.1002/ptr.2365

CORDEIRO, I.; SECCO, R.. Jatropha in List of Species of Flora of Brazil Botanical Garden of Rio de Janeiro. Growing Knowledge: an overview of Seed Plant diversity in Rodriguésia, Rio de Janeiro, v.66, n.4, p.1085-1113, 2015.

COSTA, V. P.; MAYWORM, M. A. S.. Medicinal plants used by the community of the Tenentes neighborhood - municipality of Extrema, MG, Brazil. Brazilian Journal of Medicinal Plants, Botucatu, v.13, n.3, p.282-292, 2011. DOI: http://dx.doi.org/10.1590/S1516-05722011000300006

CRISTINA, R. T.; KOCSIS, R.; TULCAN, C.; ALEXA, E.; BOLDURA, O. M.; HULEA, C. I.; DUMITRESCU, E.; RADULOV, I.; MUSELIN, F.. Protein structure of the venom in nine species of snake: from bio-compounds to possible healing agents. Brazilian Journal of Medical and Biological Research, Ribeirão Preto, v.53, n.1, p.9001, 2020. DOI: http://dx.doi.org/10.1590/1414-431X20199001 
ESTEVAO, C. M. I.; GONTIJO, S. S.; CORREIA, B. L.; YARLEQUE, A.; VIVAS-RUIZ, D.; RODRIGUES, E.; CHÁVEZ-OLORTEGUI, C.; ELADIO, L. S.; SANCHEZ, L.. Neutralization of toxicological activities of medically relevant Bothrops snake venoms and relevant toxins by two polyvalent bothropic antivenoms produced in Peru and Brazil. Toxicon, London, n.122, p.6777, 2016. DOI:

https://doi.org/10.1016/j.toxicon.2016.09.010

FARRAPO, N. M.; SILVA, G. A. A.; NOGUEIRA K. C.; SILVA, M. G.; COGO, J. C.; DAL BELO, C. A.; DOS SANTOS, M. G.; GROPPO, F. C.; OSHIMA-FRANCO, Y. Inhibition of Bothrops jararacussu venom activities by Plathymenia reticulata Benth extracts. Journal of Venom Research, Oxford, v.2, p.52-58, 2011.

FEITOSA, E. S.; SAMPAIO, V.; SACHETT, J.; CASTRO, D. B.; NORONHA, M. D. N.; LOZANO, J. L. L.; MUNIZ, E.; FERREIRA, L. C. de L.; LACERDA, M. V. G. de; MONTEIRO, W. M.. Snakebites as a largely neglected problem in the Brazilian Amazon: highlights of the epidemiological trends in the State of Amazonas. Revista da Sociedade Brasileira de Medicina Tropical, Manaus, v.48, p.34-41, 2015. DOI: https://doi.org/10.1590/0037-8682-0105-2013

FERRAZ, M. C.; YOSHIDA, E. D.; TAVARES, R. V. S.; COGO, J. C.; CINTRA, A. C. O.; DAL BELO, C. A.; FRANCO, L. M.; SANTOS, M. G.; RESENDE, F. A.; VARANDA, E. A.; HYSLOP, S.; PUEBLA, P.; FELICIANO, A. S.; OSHIMA-FRANCO, Y.. An isoflavone from Dipteryx alata Vogel is active against the in vitro neuromuscular paralysis of Bothrops jararacussu snake venom and Bothropstoxin I, and prevents venom-induced myonecrosis. Molecules, v.19, p.5790-5805, 2014. DOI http://dx.doi.org/10.3390/molecules 19055790

FERREIRA-RODRIGUES, S. C.; RODRIGUES, C. M.; SANTOS, M. G.; GAUTUZ, J. A.; SILVA, M. G.; COGO, J. C.; BATISTA-SILVA, C.; SANTOS, C.; GROPPO, F.; COGO-MÜLLER, K.; OSHIMAFRANCO, Y.. Anti-Inflammatory and antibothropic properties of Jatropha elliptica, a plant from Brazilian cerrado biome. Advanced Pharmaceutical Bulletin, Tabriz, v.6, n.4, p.573579, 2016. DOI: http://dx.doi.org/10.15171/apb.2016.071

FONSECA, F. V.; MELO, M. M.; SILVA, J.; PEREIRA, G. P.; DANTAS, B. A. M.. Extracts of Curcuma longa $L$. and Kalanchoe brasiliensis Camb, in the local treatment of Bothrops alternatus poisoning. Brazilian Journal of Pharmacognosy, Maringá, v.14, n.1, p.26-29, 2004. DOI: https://doi.org/10.1590/S0102-695X2004000300011

GALBIATTI, C.. Study of neurotoxic and myotoxic activities of a basic a2 phospholipase isolated from the Bothrops marajoensis total venom. Dissertation (Master in Medical Sciences) - State University of Campinas, São Paulo, 2008.

GOMES, J. A.; FÉLIX, S. J.; MORAIS, F. J.; AMARAL, J. G.; LOPES, N. P.; EGITO, E. S. T.; SILVA JÚNIOR, A. A.; ZUCOLOTTO, S. M.; FERNANDES-PEDROSA, M. F.. Aqueous Leaf Extract of Jatropha mollissima (Pohl) Bail Decreases Local Effects Induced by Bothropic Venom. BioMed Research International, v.3, p.13, 2016. DOI: https://doi.org/10.1155/2016/6101742

GOULART, M. O. F.; SANT'ANA, A. E. G.; LIMA, R. A.; CAVALCANTE, S. H.; CARVALHO, M. G. C.; BRAZ-FILHO, R.. Chemical phytoconstituents Isolated from Elliptical Jatropha. Attribution of the Chemical Shifts of the Carbon and Hydrogen Atoms of the Diterpenes Jatrofolones A and B.
Química Nova, São Paulo, v.16, n.2, p.95-100, 1993.

GUTIÉRREZ, J. M.; LEÓN, G.; LOMONTE, B.; ÂNGULO, Y.. Antivenoms for snakebite envenomings. Revista Inflammation \& Allergy-Drug Targets, Sharjah, v.10, p.369380, 2011.

GUTIÉRREZ, J. M.; LOMONTE, B.. Local tissue damage induced by Bothrops snake venoms: a review. Revista Memórias Instituto Butantan, São Paulo, v. 51 n. 4, p.211223, 1989.

LAEMMLI, U. K.. Cleavage of Structural Proteins during the Assembly of the Head of Bacteriophage T4. Nature, Londres, v.227, p.680-685, 1970.

LEOBAS, G. F.; FEITOSA, S. B.; SEIBERT, C. S.. Accidents by venomous animals in the state of Tocantins: clinical and epidemiological aspects. Desafios Magazine: Interdisciplinary Magazine of the Federal University of Tocantins, Palmas, v.2, n.2, p.269-282, 2016. DOI: 10.20873/uft.2359-3652.2016v2n2p269

LIMA, M. R. F.; LUNA, J. S.; SANTOS, A. F.; ANDRADE, M. C. C.; SANT'ANA, A. E. G.; GENET, J. P.; MARQUEZ, B.; NEUVILLE, L.; MOREAU, N.. Antibacterial activity of some Brazilian medicinal plants. Journal of Ethnopharmacology, Limerick, n.105, p.137-147, 2006. DOI:

https://doi.org/10.1016/i.jep.2005.10.026

MESH. Medical Subject Headings. Bethesda: US National Library of Medicine. MESH, 2020.

MILAD, R.; EL-AHMADY, S.; SINGAB, A. N.. Genus Kalanchoe (Crassulaceae): A Review of Its Ethnomedicinal, Botanical, Chemical and Pharmacological Properties. European Journal of Medicinal Plants, West Bengal, v.4, n.1, p.86-104, 2014. DOI: https://doi.org/10.9734/EJMP/2014/5901

MOURA, V. M.; MOURÃO, R. H. V.; SANTOS, M.. Ophidian accidents in the Northern Region of Brazil and the use of plant species as an alternative and complementary treatment to serotherapy1. Scientia Amazonia, Manaus, v.4, n.1, p.73-84, 2015

NISHIJIMA, C. M.; DELELLA, F. K.; RODRIGUES, C. M.; RINALDO, D.; LOPES-FERREIRA, M. V. A.; ROCHA, L. R. M.; VILEGAS, W.; FILISBINO, S. L.; HIRUMA-LIMA, C. A.. The AntiInflammatory Effects of the Methanolic Extract and Fractions from Davilla elliptica St. Hil. (Dilleniaceae) on Bothrops jararaca Envenomation. International Journal of Molecular Sciences, Switzerland, v.16, p.12454-12466, 2015. DOI: https://doi.org/10.3390/ijms160612454

OLIVEIRA, F.; SOUSA, B. B.; MAMEDE, C. C. N.; MORAIS, n.C. G.; QUEIROZ, M. R.; PEREIRA, D. F. C.; MATIAS, M. S.; BRANDEBURGO, M. I. H.. Biochemical and functional characterization of BmooSP, a new serine protease from Bothrops moojeni snake venom. Toxicon, London, v.111, p.130-138, 2016. DOI:

https://doi.org/10.1016/j.toxicon.2016.01.055

OLIVEIRA, I. C. F.; MORA, A. D.; NETO, J. B.; OLIVEIRA, Á. L.; HARDER, C.; HANAI-YOSHIDA, V. M.; COGO, J. C.; FLORIANO, R. S.; JUNIOR, W. B.; OLIVEIRA, S. J.; OSHIMA-FRANCO, Y.. Prospective study of a Bothrops jararacussu venom batch (Bj2015) - phospholipase A2 activity, immunogenicity, neurotoxicity, and myotoxicity parameters. Natural Products Research, London, v.33, n.16, p.2417-2421, 2019. DOI: 
https://doi.org/10.1080/14786419.2018.1446010

OSHIMA-FRANCO, Y.; DAL BELO, C. A.. Recognizing Antiophidian Plants Using the Neuromuscular Junction Apparatus. International Journal of Complementary \& Alternative Medicine, Edmond, v.5, n.5, p.00165, 2017.

PAULA, R. C.; SANCHEZ, E. F.; COSTA, T. R.; MARTINS, C. H. G.; PEREIRA, P. S.; LOURENÇO, M. V.; SOARES, A. M.; FULY, A. L.. Antiophidian properties of plant extracts against Lachesis muta venom. Journal of Venomous Animals and Toxins Including Tropical Diseases, Botucatu, v.16, n.2, p.312, 2010.

PESSOA, C.; FARIA, M. H. G.; SANTANNA, E.; LEYVA, A.; VALLE, C.; MORAES, M. O.. Investigation of the cytotoxic and antitumor activities of Jatrofona. Electronic Journal of Medical Research, Fortaleza, n.1, p.114, 2007.

PESSOA, C.; SANT'ANNA, E.; LEYVA, A.; VALLE, C.; MORAES M. O.. Evaluation of antitumor activity and cytotoxicity of Jatrofone, a diterpene extracted from Jatropha elliptica Muell Arg. Brazilian Journal of Pharmacognosy, Curitiba, v.80, n.3-4, p.59-60, 1999.

PINHO, F. M. O.; PEREIRA, I. D.. Ofidism. Magazine of the Brazilian Medical Association, São Paulo, v.47, n.1, p.24-9, 2001.

PUEBLA, P.; OSHIMA-FRANCO, Y.; FRANCO, L. M.; DOS SANTOS, M. G.; SILVA, M. G.; RUBEM-MAURO, L.; FELICIANO, A. S.. Chemical Constituents of the Bark of Dipteryx alata Vogel, an Active Species against Bothrops jararacussu Venom. Molecules, Basel, v.15, n.11, p.8193-8204, 2010. DOI: https://doi.org/10.3390/molecules15118193

RIBEIRO, L. A.; ALBUQUERQUE, M. J.; CAMPOS, V. A. F.; GATZ, G.; TAKOADA, N. Y.; LEBRÃO, M. L.; JORGE, M. T. Deaths by venomous snakes in the State of São Paulo: evaluation of 43 cases. Magazine of the Brazilian Medical Association, São Paulo, v.44, n.4, p.312-318, 1998.

RODRIGUES, L.; CUNHA, D. B.; LEITE, G. B.; OLIVEIRA, C. R. B. CINTRA, A. C. O.; RODRIGUES-SIMIONI, L.; OSHIMA-FRANCO, $Y$.. Heparin action against myotoxin neurotoxic activity Bothropstoxin-I. Health in Review, Piracicaba, v.6, n.14, p.19-29, 2004.

SANTOS, M. G.; LOLIS, S. F.; DAL BELO, C. A.. Ethnobotanical surveys carried out in two communities of remnants of blacks in the region of Jalapão, State of Tocantins. In: PIRES, A. L. C. S.; OLIVEIRA, R.. Black Sociabilities. Remaining Communities, Slavery and Culture. Belo Horizonte: Daliana Ltda., 2006. p.29-49.

SEGURA, Á.; HERRERA, M.; VARGAS, M.; VILLALTA, M.; USCANGAREYNELL, A.; LEÓN, G.; GUTIÉRREZ, J. M.. Preclinical efficacy against toxic activities of medically relevant Bothrops sp. (Serpentes: Viperidae) snake venoms by a polyspecific antivenom produced in Mexico. Revista de Biologia Tropical, San José, v.65, n.1, p.345-350, 2017.
SILVA, J. O.; FERNANDES, R. S.; TICLI, F.K.; OLIVEIRA, C. Z.; MAZZI, M. V.; FRANCO, J. J.; GIULIATTI, S.; PEREIRA, p. S.; SOARES, A. M.; SAMPAIO, S. V.. Triterpenoids saponins, new metalloproteinase snake venom inhibitors isolated from Pentaclethra macroloba. Toxicon, London, v.50, p.283, 2010.

SILVA, R. C. C.; FREITAS, M. A.; SANT'ANA, S. S.; SEIBERT, C. $S$.. Snakes in the state of Tocantins: illustrated guide. Dissertation (Master in Environmental Sciences) - Federal University of Tocantins, Palmas, 2017.

SILVA, S. M. P.; COELHO, M. F. B.; SILVA, A. M.. Phenological aspects of lizard purging (Jatropha elliptica M. Arg. Euphorbiaceae) in Santo Antônio de Leverger - MT. Brazilian Journal of Biology, São Carlos, v.58, p.301-306, 1998.

SOARES, A. M.; TICLI, F. K.; MARCUSSI, S.; LOURENÇO, M. V.; JANUÁRIO, A. H.; SAMPAIO, S. V.; SAMPAIO, S. V.; GLIGIO, J. R.; LOMONTE, B.; ,PEREIRA, P. S.. Medicinal Plants With Inhibitory Properties Against Snake Venoms. Current Medicinal Chemistry, Sharjah, v.12, p.2625-2641, 2005. DOI: https://doi.org/10.2174/092986705774370655

TRIBUIANI, N.; SILVA. A. M.; FERRAZ, M. C.; SILVA, M. G.; BENTES, A. P. G.; GRAZIANO, T. S.; SANTOS, M. G.; COGO, J. C.; VARANDA, E. A.; GROPO, F. C.; COGO, K.; OSHIMAFRANCO, Y.. Vellozia flavicans Mart. Ex Schult. Hydroalcoholic extract inhibits the neuromuscular blockade induced by Bothrops jararacussu venom. BMC Complementary Alternative Medicine and Therapy, Sacramento, v.14, n.48, 2014. DOI https://doi.org/10.1186/1472-6882-14-48

VAN DER BERG, M. E.; SILVA, M. H. L.. Contribution to the medicinal flora of Mato Grosso do Sul. Revista Acta Amazônica, Manaus, v.18, p.9-22, 1988. DOI: https://doi.org/10.1590/1809-43921988185022

VILAR, J. C.; CARVALHO, C. M.; FURTADO, M. F. D.. Ophidism and plants used as antiophids. General and Experimental Biology, Boa Vista, v.6, n.1, p.3-36, 2005.

W.H.O. World Health Organization. Guidelines for the production, control and regulation of snake antivenom immunoglobulins. WHO, 2018.

YAZBEK, P. B.; TEZOTO, J.; CASSAS, F.; RODRIGUES, E.. Plants used during maternity, menstrual cycle and other women's health conditions among Brazilian cultures. Journal of Ethnopharmacology, Constanta, v.179, p.310-331, 2016. DOI: https://doi.org/10.1016/i.jep.2015.12.054

YIN, W.; WANG, Z.; LI, Q.; LIAN, J.; ZHOU, Y.; LU, B.; JIN, A.; QIU, P.; ZHANG, P.; ZHU, W.; WEN, B.; HUANG, Y.; LIN, Z.; QIU, B.; SU, X.; YANG, H.; ZHANG, G.; YAN, G.; ZHOU, Q.. Evolutionary trajectories of snake genes and genomes revealed by comparative analyses of five-pacer viper. Nature Communication, Londres, n.7, p.13107, 2016. DOI: https://doi.org/10.1038/ncomms13107

A CBPC - Companhia Brasileira de Produção Científica (CNPJ: 11.221.422/0001-03) detém os direitos materiais desta publicação. Os direitos referem-se à publicação do trabalho em qualquer parte do mundo, incluindo os direitos às renovac̃es, expansões e disseminaçoes da contribuiç̃o, bem como outros direitos subsidiários. Todos os trabalhos publicados eletronicamente poderão preservam os direitos autorais, mas não têm permissão para a publicação da contribuição em outro meio, impresso ou digital, em português ou em tradução. 